\title{
Revisiting the role of conflict in media events: The Argentine Bicentenary
}

\author{
Maximiliano E. Korstanje ${ }^{1 *}$
}

Received: 19/03/2011 Accepted: 03/08/2011

\footnotetext{
${ }^{1}$ Department of Economics, University of Palermo, Argentina, email: maxikorstanje@fibertel.com.ar

* Corresponding author
}

\begin{abstract}
The Argentine Bicentenary, celebrated in 2010, was unique in many aspects, not only since the event is being celebrated every hundred years, but also because this contrast with everything that is written in event-management literature hitherto. The belief that mediated-events are aimed at achieving social cohesion reinforcing the solidarities among attendants was put under the lens of scrutiny. Under certain conditions, the social conflict augments in these types of festivals, first and foremost, whenever it cannot be regulated by the state. This research focuses on the following relevant aspects, The Bicentenary potentiated long-simmering disputes between two contrasting discourses and gazes in the political fields. Distorted images of centenary from one side or another, give the preconditions for the advent of a stronger discourse that revitalize the heritage and helps citizenship understanding what being argentine means. As a mediated-event, bicentenary emphasized on values based on nation-hood and pride for national symbols in citizenship. However, politicians seemed to broaden their profound political discrepancies in this event, contrasting exactly what specialized literature claims.
\end{abstract}

(c) 2012 International University College. All rights reserved

Keywords: events, nationalism, ethnocentrism, conflict, Cristina F. de Kirchner, Mauricio Macri.

Citation: Korstanje, M. (2012) Revisiting the role of conflict in media events: The Argentine Bicentenary. European Journal of Tourism Research 5(1), pp. 53-67

\section{Introduction}

In last decades, many policy-makers and planners utilized event-management as a form of boosting the image in some touristdestinations by developing new skills in the way communities organize themselves. To some extent, festivals contribute to revitalize the heritage, customs, tradition boosting the community's pride or as a creative instrument to enhance involving destination's attracti- veness (Abyssal and Wicks, 1993; Crompton and Mckay, 1997; Molloy, 2002; Prentince and Anderesen, 2003; Gonzalez-Reverté and Miralbell-Izard, 2009; Whitford, 2009; Chew, 2009; Saayman and Saayman, 2006; Gelder and Robinson, 2009; Getz and Andersson, 2009; Tassiopoulous, 2005; Mallen and Adams, 2009; Cieslak, 2009; Prebensen, 2008). In this vein, Crompton and Mckay suggest that six motives domain in visitors at 
the time of participating in a festival: cultural exploration, novelty, recovery needs, socialization, external interaction and gregariousness (Crompton and Mckay, 1997). Other effects of festival organisation are strictly related to the change of image for community (Prentice and Andersen, 2003) or political problems between guest and hosts (BerlangaAdell, 2004). T. A. Binoy infers convincingly that media-events allow a deep-seated interpretation of what heritage represents. But to some extent, heritage interpretation would be a sociological process of conveying and transforming certain information in a comprehensible meaning of past (Binoy, 2011).

Nonetheless, less attention was given to the role of conflict in mediated-events, or festivals. In such a context, the present paper intends to fulfill this gap contending the thesis of Dayan and Katz (1994) along with the connection between previous disputes and the pride of belonging. From their perspective, mediatedevents are two functions: a) reducing the historical conflicts among stakeholders, and b) revitalizing the cultural and national values engendering a broader sentiment of brotherhood in attendants. Rather, our research showed how Argentine celebrations for the Bicentenary opened the door to potentiate early points of discussion between Mauricio Macri (Mayor of Buenos Aires city) and Cristina Fernandez de Kirncher (President). This troublesome encounter, far away of being mitigated or diminished, has been potentiated to the extent that the latter opted not to attend at inauguration of Colon Theatre (one of the most important theatres of country in arts and dancing).

\section{Literature Review}

The specialized literature emphasizes on tourism as an agent capable of multiplication of incomes and revitalizations of cultural heritage of some developing countries. The masstransport and mobilities that characterized the life of former centuries are now commercialized in a world that prioritises travels as a social distinction. Late-Modernity allows a broader convergence between future and tradition. For example, nowadays American Irish-descendants and visitors, who arrived from Ireland half century ago, are now visiting Ireland in a quest for their ancestral roots. Looking for stories, music, traditional dishes and lore, thousand of tourists in the world frequently traverse the Ocean back and forth. For them, festivals represent the legacy of an ancient discourse enrooted in the pride "of being Irish" (Wright, 2010).

Following this, Jonker, Saayman and De Klerk recognize (from original six) three crucial factors for shaping entrepreneurs in the role as managers of events. Festival promotion (factor 1) and product promotion (factor 2) are associated to the necessary endeavor in promotion and commitment of local resident in advertising the event in neighboring zones. Income generation refers to profitability which allows the event can be repeated in next year. For authors, personal satisfaction and making money are two important elements in festivalsmanagement (Jonker, Saayman and De Clerk, 2009: 389). In addition, Gonzalez-Reverté and Miralbell-Izard envisage that festivals make feasible a further concentration of activities opening the doors for developing certain products and improving the chances of a destination to entice international visitors. From this perspective, events fall into a conceptual fourth-fold model: a) event as brand builders, b) events as indirect business generator, c) events as tactical levers and d) events as a vehicle for local pride. The synergy in festivals is associated with possibilities of orchestrating tangible and intangible resources. However, there are some obstacles that jeopardize the enhancement of a destination linked to the indifference of political power, as well as certain inadequacy along with the season cut-off (Gonzalez-Reverté and Miralbell-Izard, 2009: 54). In perspective, D. Getz adds that probably the majority of events have arisen due to no tourist-motives, but in the last years, there was a clear penchant to exploit and create tourist attractiveness which seems to be unquestionable. The visitor experience often combines tangible and intangible products, but what is more important here is the novelty all these sites express (Getz, 1991). This point of discussion raises the question to what extent media-events need history and heritage to create attractive destinations. 
Based on the assumptions, heritage is not formed by the past, but a careful selection of certain past events, G. Ramshaw implies that even if heritage as a narrative has its roots in nineteenth century, in modern tradition and history pivoted the main concerns of scholarship. However, sometimes scholars confuse the role played by heritage and heritage narrative in social life. Whereas heritage corresponds with a human ability placed in cultural dimension to make emphasis on identity, heritage narratives refer to a mystification of certain aspects of culture given in some contexts. The problem is not how authentic heritage is, (because it is a human construction - always subjective about reality) but how it decodes the significance of self in respect to others (Ramshaw, 2011). This selective "mining of past" creates an imagined future by means of the orchestration of certain past-events which are motive of pride for community (Ashworth, 2008; Graham et al, 2000). Not necessarily, this means that heritage lies, but it can be manipulated depending upon the contextualization of political settings, in what anthropologists know as the legacy. Unlike history, the legacy seems to be a biased narrative that mythically gives order to contemporary behaviour. Events and festivals act as conduits in the formation of shared-values and customs that facilitate the community's identities. In doing so, the conflict should be temporarily situated towards the boundaries of group. For that reason, one might realize that the social cohesion in festivals situate themselves in opposition to the rivalry with other groups. At times, groups appeal emotionally to festivals and heritage, the social conflicts seems to be suspended but, as we shall see in this research, this does not always happen.

\section{Media Effects on Festivals}

A long-term investigation conducted by Ritchie, Sanders and Mulles, along with the capital city of Camberra in Australia, showed how influence, exerted by televising and mediated events in the destination-image, changes audience's behavior in a considerable manner. The previous experience plays a crucial role in shaping the psychological expectancy in consumers. Those attendants, who had a good experience of other events, or were exposed to mediated-news in regards of certain Festival, will develop a more positive image than other ones (Ritchie, Sanders and Mules, 2007). Therefore, sporting and media events are functional to the preservation of an organic image of destinations. In addition, J. Molloy contends that festivals attending entail a new form of entertainment which can be driven towards a relaxation and socialisation purposes as a familiar climate wherein fun and excitement predominate. This course of action not only increases the quality of life but also integrates economic and human resources for development. In these types of events, Molloy accepts that the state intervenes with financial aid not only to protect the resources of community but also to follow further legitimacy or pursuing politic interests (Molloy, 2002).

In addition, Berlang-Adell visualizes how tourism and power converge in the same arena. The ancient territorial disputes with the local government are often reinforced in these types of events, while tourism tends to create a new depiction homogenizing the ethnic diversity that takes part of festivals. In this case, tourism appears to be functional to the preservation of political status quo, whereas residents re-signify their ancient rituals and feasts along with the needs of market (Berlang-Adell, 2004). In previous studies, Korstanje sets forward a model to explain how the national archetype is gradually labeled following specific political interests. Four variables were involved in this process: charisma, nationalism, hegemony and sacrifice. The latter one worked as a mechanism of social distinction (Korstanje, 2008). To some extent, mass media not only replicates the beliefs, stereotypes and ideas according to certain issue but also paves the pathways towards the onset of a political ethnocentrism (Lorge, 1936) (NoelleNeumann, 1995) (McQuail, 1999) (Baudrillard, 1997). What is important to note here is that mass media elaborates an organic and allencompassed discourse respecting to events with the ends of reinforcing cultural and moral values which shape the society as such.

Besides, it is important not to loose the sight of the role played by the mass media and journalism in the conformation of national- 
mythical archetype in circumstances of wars or sport competitions. After a detailed examination of 12 festivals throughout Australia, J. Molloy considers that geographical proximity between main larger cities and small rural areas are not an exclusive prerequisite in order for the community to support potential festivals. The author goes on to say that "representing the relationships in this graphical way tends to negate the suggested alternative hypothesize that size of community rather than isolation is more relevant. Some of those centres which are shown as having the strongest community support are relatively small in terms of population while other with strong support have much larger population" (Molloy, 2002: 12).

Of course, the community support depends upon the degree of benefits or well-being involved stakeholders perceive. A further contemplation reveals that a purchasing power that visitors spent in the zone is more than important to take for granted the festival's success. This work does not explain to what an extent the political power can manipulate in their favor these types of events. As the previous argument given, Hill and Varrasi noted how the mythical Wembley's stadium in England, for instance, was created following an effort to remind the British strength and the golden times of British Empire (Greatness). Sometimes, these types of projects operate under the pretext to help people alleviating poverty and unemployment but with the passing of days, politicians created around them an specific speech (Hill and Varrasi, 1997).

From an anthropological point of view, festivals as well as events have an epicenter based on the allegoric construction of meaning in relation to a certain theme which concerns the involved community. Sometimes they refer to how it administers the existing resources of environment or issues linked to economy where there is a convergence of natural elements such as air, water, nature, storm or other forces. Events and festivals must be understood as rituals or rites of passages where attendants' identities are in ongoing renegotiation. The essence of these rituals resolves the cultural contradictions between death and life. For example, societies had serious problems to intellectualise the death of youth, children or off-springs. Because of biological cycles, they are supposed to live more time than current generations. Festivals, under such a context, represent not only certain aversion to poverty and shortage expressed in the figures banquets, drink and food but also emulate the lost paradise by means of exacerbation of neatness, beauty, and harmony. Festivals are temporarily characterised by the sublimation of all inner disputes among participants. As previously noted, one of the elements that predominates in Festival tourism are food, drinks, children, fertility of lands and maids.

\section{Sociological Aspects of Events}

Dissuasively for Ancient Greeks, Olympic Games had the function to prevent the prosecution of war among involved folks. As N. Spivey argued, the roots of these games roughly stemmed from 770 B.C in which case different athletes participated with the end of gaining glory and fame for their off-spring. The religious nature of these festivals worked as a form of dissuasion for participant communities not to enter in a real conflict (Spivey, 2004). Like a travel in a quest of the heritage, Ancient Olympic Games represented a question of genealogy for stakeholders. Participants in these types of games were affiliated to a gen (clan) as well as personal name which should transcend the boundary of time. The victory not only signified the blessing of gods for participants and their cities but also the assumption their names will be recalled for eternity. Even though nowadays things appear to be changed, international sporting competitions are still a platform for participants to access to an uncalculated richness and fame. The nation plays a crucial role in the construction of much broader archetype circumscribed to heroism. However, one of the limitations of ancient literature in the examination of event management is the lack of a nation-state as we know it today. The traditional sociological literature has emphasized on key factors which intervene in the inception of the nation-state. The capacity of human beings for prosperity or transforming the local resources in their favor is 
unquestionable reality. However, our times characterizes by the hegemony of mobility and speed (Guicci, 2007) (Urry, 2007). The sport competitions distinguished themselves by being ascribed to a criterion of superiority before other men and nature.

On the other hand, nation-states capitalise their achievement and failures according to two main logics: a) the concreteness of certain goals and b) the flaws occurred in the process of achievement. In regards to this, the morality of an institution is not only associated with the aims but also reinforces the principle of instrumentality (Hardin, 2003). It is important to mention that the state establishes the greatness of sportsmen homogenizing previous and divergent ethnic affiliations. That way, China, ex-URSS, even the United States or Argentina as symbolic sonstructions that usually join a dearth of other unvoiced folks recreate a coherent and all-encompassed image of themselves in Olympic Games. In success or in failure, the nation-state reproduces a much broader sublimation process we recognize as nationality with the end of absorbing the discrepancies that impinge on the system (Briones, 1998). It is not surprising to realize how industrialized countries occupy the first ranking-positions in sport games while non-industrialized countries are relegated to secondary slots. For the British anthropologist C. Geertz, nationalism and inception of the nation-state are a process that encompasses four stages: a) formation, b) legitimacy, c) an articulation of diversity, and d) consolidation of an image under a homogenized ideology. The Golden Times are a concept that is frequently evoked in these kind of movements. Returning to founding myths is one of the main concerns of leaders to gain more legitimacy in their practices (Geertz, 2005). In this vein, K. Hollingshead illustrates how nation-states play a crucial role not only in the world-making process to create heritage and tradition in certain circumstances but also by labelling corporeally a set of diverse identities in like-minded individuals who dwell between fantasy and reality. Always negotiable, these identities represent powerful models to determine the sense of surrounding events (Hollingshead, 2009).
The hero has morphologically played a divine intermediating role between the Gods and human beings. The nature of heroes corresponds with a combination of immortality and acceptance of death. Almost all heroes, such as Gilgamesh, Christ, Siegfried, Aquiles or even Oedipus, are characterized to overcome a scenario fraught with threats and obstacles in remote lands, oddly for avarice, pride or ignorance - in the case of Oedipus the hero assassinates to an innocent or commits an appalling crime. This offence works as scapegoat for the forthcoming events for what the hero should be redeemed. As the previous argument given, F. Bauza argues that heroism is a social construction people usually elaborate to enhance their self-esteem of community that under some circumstance would range from a pleasant lapse of relax to a serious sentiment of superiority or chauvinism (Bauza, 1998). Actually, an ever growing number of sportsmen recur to professional competition in the search of social distinction, fame and recognition. For a part of the third world, families encourage their sons to play soccer or other discipline as a form of alleviating the poverty and improving material conditions wherein they live; in the first world countries invest a considerable amount of money in training their athletes. Even if classical anthropology has devoted considerable attention in the study of myths in aboriginal tribes, less attention was given to the influence of mythical archetype in modern sports in industrialised societies.

In an earlier research, Korstanje showed convincingly that the historical roots of event management as we know it today stems from Ancient Rome. Covering more than 123 years of history, this study showed how leisure, sports, and events are functional to political power because, on one hand, it revitalised the pride of being part of the Roman Empire, and secondly, worked as an instrument of alienation wherein financial disruptions, economic problems and frontiers revolts were momentarily ignored. Starting from the premise that Rome mythology encouraged conflicts, confronting sons against their fathers due to the glory, fame, and power, which were the values a child learned from the cradle, events symbolized the supremacy of Romans over 
other civilizations and, of course, over nature. Their technology that pushed towards expanding their limits up to transform this town in one of greatest empires of the known world, was over-emphasized in arts and all public spectacles. Under such a circumstance, leisure worked as a vehicle towards hegemony and ideology, preventing social fragmentation as well as encouraging a rural migration to urban cities. As a fruitful mechanism of political indoctrination, something else than a new way of improving business or enhancing touristdestination attractiveness, events are constructed around a one-sided gaze of past times (ethnocentrism) which emulates the "golden times", a supposed superiority or the mythical archetype that founded the society. Values linked to instrumentality, pride, technology and superiority seem to be present in all festivals and mediated events.

\section{Understanding the social conflict}

Lewis Coser was one of the pioneers in examining the role played by social conflict in human groups. This American scholar who was influenced by two contrasting waves: the functionalism and the ethno-methodology of Chicago, the conflict can be defined as a mechanism aimed at solidifying a loosely structured group avoiding the social fragmentation of their members. The social conflict, to put this brutally, seems to be an efficient strategy to forge the identity of the self simply because this produces cohesion and self-importance. Intra-group conflict serves as a mediator in the process of communication. Groups, in a previous stage, remain unsure in respect to their own interests and stances, but after a conflict, the positions and boundaries among groups are clearer. Beyond the nature of the conflict, whether it is real or unreal, Coser explains that the physical proximity plays a pivotal role in enhancing or diminishing the severity of hostility among actors (Coser, 1961). Rather, Boulding suggests one of the most efficient strategies to prevent conflicts seems to be the indifference. From this point of view, the contact (under certain conditions) aggravates the disputes and their degrees. At a first glance, whenever conflicts are not regulated by a superstructure or power, the lack of contact is a valid alternative (Boulding, 1962). The linkage between social conflicts and sports is not new. Many spectacles have contributed to acts of violence and hostility among attendants simply because events resignify the past, but echo the old enmity at the same time by means of stereotypes and existent prejudices.

In addition, Tajfel and Turner (1986) demonstrated that if social identity is fragmented or threatened by some perceived risk, people develop a substitute mechanism to regulate anxiety and fears. The main thesis is that social identity is formed by conflict and aggression against members foreign to the group. From such a point of view, the prejudice, as a social construction, not only becomes a mechanism of distinction but it also facilitates the social cohesion (Tajfel and Turner, 1986). Thus, psychological identifications with social groups are determined by certain situations and contexts. With respect to out-group prejudices and social dominance, Pratto et. al (2003) found that after shocking events, such as September 11, prejudices and stereotypes are accommodated according to a much deeper hierarchal logic. A couple of days after this crippling attack, they observed a dichotomy of behavior between Americans and Lebanese students. While American feared that US would lose its dominance, predominance and protagonist role in the world, Lebanese students hoped for US decline in predominance in international political issues. From this point of view, authors proved not only fears and hopes are interrelated to prejudice and stereotypes but also political and patriotic issues (Pratto, et al. 2003).

The volatile nature of tourism, sports and festivals lead us to believe that contact theory coined by Allport (1977) is a fertile source to be explored in this research. He compiled erudite studies recorded during the 10 years of research into prejudice and discrimination. From his perspective, subjects have a natural tendency to organize their world by the employment of cognitive stereotypes. Under these circumstances, stereotypes have the function to save mental energy in remembering all time the same past events. Undoubtedly, one of the contributions of G. W. Allport (1977) to this topic seems to be the connection between contact, negative stereotypes and 
prejudice. Similarly, Mussen and Yarrow carried out experiments with youths in a summer vacation resort and agreed that where contact arises between intergroup members, prejudice falls (reported in Allport, 1977). Allport's works validated the idea that the geographical and psychological proximity between stakeholders is not only a conduit for prejudice but encourages the conflict in them (Brown, 1998; Sherif and Sherif, 1953; Stouffer, 1949; Brewer and Campbell, 1976). On the contrary, Park criticized contact-based studies because the interactions appear not to suffice in decreasing prejudice in contexts of scarce control (Park, 1939). In accordance with Park's criticism, Sherif and Sherif observed that prejudice increased at the time incompatibility in common group interests appears. From their perspective, competence is one of more important variables that would explain why prejudices and hostility emerge (Sherif and Sherif, 1953). Other similar studies validated the previous findings of Sherif and Sherif (Seago, 1947; Brown, 1998; Maclver and Page, 1966; Pratto et al., 2003). More than one decade ago, Dayan and Katz (1994) introduced a new thesis in the conflict theory studies. They considered that event management and festivals allowed ordinary people not only to give a sense for their lives and future, but also paved the ways for the rise of a spirit of brotherhood among the in-group members. Paradoxically, the narrative (discourse) these types of festivals generate provokes hostility against out-group members. Hitherto, this stance validates the studies of Seago, Brown and even Allport in respect to the relationship between self and others, but sometimes, as we will examine in this research, Events engender hostility inside the group contrasting to everything written in specialized literature.

\section{Causes of Conflicts between Argentina and United Kingdom}

The history of disputes between Argentina and United Kingdom has been enrooted to the interests of both countries to Malvinas/Falklands; an archipelago in the South Atlantic Ocean, located approximately 250 nautical miles from the coast of mainland South America. Although, France was one of the first countries that settled in the Falklands in 1764, these islands were under the protection of United Kingdom until the Utrecth's covenant where the latter one was obligated to bestow the sovereignty to Spain. After hard negotiations, England abandoned Malvinas in 1774 to return almost 60 years later (Peterson, 1986). Once the independence from Spain was successfully achieved, Argentina took possession of these islands as part of its sovereignty. In 1823 Lewis Vernet was appointed Governor of Malvinas. Vernet launched to abide the existent legislation monitoring the troubling fishing of American and British vessels. Convinced that the dissuasive policies conducted by Argentina were not enough to prevent the illegal fishing in the zone, Vernet unilaterally decided to host the crew of Harriet and Breakwater ships triggering the first diplomatic misunderstanding between US and Argentina. As a result of this, capitan Duncan, the commander of Lexington Frigate who was sailing close-up Malvinas gave to Buenos Aires a downright ultimatum in order for Harriet's crew to be set free intermediately. Since Argentine president Anchorena disobeyed Duncan's claims, the latter one went to Malvinas and hosted to Vernet. Taking advantage of the chaos and lack of government in the Malvinas, United Kingdom took militarily possession of the islands. Since 1832, Argentina and United Kingdom repeatedly disputed the sovereignty of Malvinas in a diplomatic manner (Peterson, 1986).

However, in 1982 argentine president Fortunato Galtieri, speculating on the support of US which never materialized, invaded the Malvinas initiating a war between Argentina and England which would take a couple of months. On April 2 of 1982, thousands of Argentines congregated at "Plaza de Mayo" to support the invasion and proclaimed the same as a "heroic gesture". In Buenos Aires, things moved from worse to worst. By keeping the facts under censorship, the public opinion was substantially manipulated to believe that Argentina was winning a war when 2000 people were already dead and 2000000 dollars were already spent as if it were to a black hole. Following this, the military forces proceeded to a question the commandment of Galtieri opening an investigation that led Galtieri to cede the presidency to Bignone. Last, on 30 
October of 1983, a democratic vote was celebrated in Buenos Aires and the rest of the country where Raul Alfonsin was elected president. The end of this dictatorial government (initiated in 1976) represented for citizenship more than 30.000 dissidents assassinated and serious financial problems (Winter and Rins, 1996). In addition, Malvinas/Falklands is today a reminder of atrocities perpetrated by the last military bloody dictatorships but also this episode evokes how important democracy is for the Republic life and peace. In recognition to this, Angular considers that Argentine nationalism exacerbated after the World Football Championship of 1978 and the latter invasion to Malvinas ushered the country towards a down-right political failure that marked the irreconcilable tension in the core of society among supporters and detractors of dictatorship (Agulla, 1986). As the previous argument given, one might speculate that football, sovereignty and conflicts have inextricably intertwined in the relationship between Argentina and England.

In 1986, the FIFA World Cup was held in Mexico because of economic and security reasons; from 31 May to 29 June to be exact (the second discarded option was Colombia). In such a tournament, Argentina was certainly enthralled thanks to the "hand of god goal" where the Diego Maradona scored the first goal for Argentina in an encounter (in quarterfinals) against England; a score illegally done with the hand. The second goal was valorized as one of the best goals in the history of World Cups. Ultimately, Argentina was the champion beating Germany $3-2$ in the final but the game against England was emotionally lived by Argentines in view of the Malvinas wounds. To some extent, Malvinas was evoked by means of a football encounter that had nothing to do with the conflict as such, but somehow continued with the sentiment of hostility in Argentines for Englanders. The memorable goals of Maradona in Mexico 86 against England will be evoked in almost all public festivals managed by the state where two primary aspects predominate: a) the sentiment of patriotism in such a game involved all Argentine players reminding the Malvinas Wars, and b) sovereignty questions related to the dignity shattered after the military beat in Malvinas (this nourishes a sentiment of superiority). These combined factors are of paramount importance to expand the current understanding of what Argentines feel about Diego A. Maradona and Great Britain and, of course, their connection with sports and ethnocentrism.

\section{Media Events}

Sports and media events serve as fertile conduits for diplomacy among nation-states. M. Polley examined in his research to what extent the Cold-War and North-Korea's classification to World Cup FIFA 1966 in England is connected with wider political and diplomatic issues not only in respect witho the reluctance of England to recognize NorthKorea as an independent state, but also not to tackle the German situation, similarly where East and West were ideologically divided. In this insight paper, Polley realizes that events, sports, conflict and nationalism are inextricably intertwined (Polley, 1998). Even though, one might recognize that press and mass media have been historically aimed at creating certain sensationalist atmosphere than accuracy in connection to sports and festivals, their importance in shaping the public opinion should not be trivialized (Mason, 1993).

Certainly, events are consumed with stronger emotional attachments to the extent of being mediated and distributed by the media. Almost always, events are expected to return financial investments to managers. For that, event management was a fertile conduit for managerial studies. To some extent, rationality and profit logic seems to be at odds with the necessary romanticism these types of festivals require. Beyond the control and expectations of the organizers, conflict and violence may very well surface spontaneously. However, one might speculate that now the advances in technology and information nourish specific narrative aimed not only at improving the quality of the spectacle but the elaboration of a coherent image for attendants. Of course, events can be seen as a mixture between the past and the future. Early history is a witness of festivals and event management, first and foremost, in case of shortages or famines. As something different than a cultural 
entertainment prone to exploit questions related to heritage and legacy, events correspond with broader human penchant to symbolize the presence of uncertainty (Robinson, Wale and Dickson 2010). Rather, Dayan and Katz emphasize on the fact mediated events are aimed at decreasing the social conflicts revitalising the trust and social liaison among attendants. As rites of passage whose ends are to reduce the degree of uncertainty, these events are characterised by the temporal suspension of conflict and historical disputes (Dayan and Katz, 1994).

Following the development in Dayan and Katz, sociological characteristics of mediated events are associated to the following issues: a) a ceremonial performance based on two main tasks, "1) to show that the utopia as modeled has always been a driving force in the life of society, such that collective memory exhibits traces of continuous aspiration toward it, and 2) to confirm the feasibility of the proposed transformation by investing the wealth of aspirations in a popular program of action" (Dayan and Katz, 1994: 180). A media event ranges from an Olympic Games organization to festivals, marriages and funerals. To clarify, even if the word media could be indentified by popular wisdom close to the use of television, this is not the case. Media refers to every aspect of human life that are public and reinforce the social commitment in day-to-day issues.

One might acknowledge that effects of mediated events are intended to prevent the social fragmentation reinforcing the selfesteem of the entire group. That way, moments of instabilities or uncertainty are a prerequisite for the management of events. This happens because the preexisting cultural values are often manipulated by privileged stakeholders for their own benefits. In this context, the elite is prone to fabricate facts as they really occurred in history giving their proper meaning of events with a specific discourse nourished by a sentiment of belonging. The Dayan and Katz's model holds 7 relevant aspects of media-events performance:

1) Media Events reinforce the legitimacy of privileged groups or aristocracies reducing the conflicts and disputes for power to a minimum degree.

2) Previous disputes or economic imbalances are blurred whenever organisers manage an event. They are based on the needs of novelty enrooted in the future, a need that lead willynilly involved stakeholders to forget the present.

3) Officials, governors and leaders in media events are casted in mythic roles which are replicated in contests or competitions.

4) A new organization of boundaries is provided after media event management. It can be said in this issue that these events provide with a new terminology or neologism in the existing language. This seems to be the case of heritage and patrimony often linked to festivals and event management.

5) Media events emphasizes on a supposed technological superiority of involving participants.

6) Media events play a pervasive role at time of creating political advertising. Not only they can put under scrutiny the role of criticized leader but also boost the legitimacy of a person or a group in few hours. Like a dream, mediated events work as a mechanism of ideology.

7) One of the respects of Event management is aimed at shortening the existing distance between leaders and citizens. Moreover, media events provoke potential effects of disasters to re-channel the consumption towards specific directions.

Sociologically speaking, festivals and media events represent a sacred time wherein people give sacrifices and gifts to their Gods in order for their economical situation and genealogy to be protected and secured. For that reason, the terms cult, cultivate and culture share the same roots. What is important to observe here is that events are functional to social cohesion by group revitalisation of sentiment of belonging. During this process, the social conflict momentarily is diminished. Rituality and ceremonies are more than significant in these events due to a minor failure that can be expressed by God's discontent and wreak havoc in economies. This suggests the belief that media events and festivals, despite the degree of technology of today in respect to Ancient times, symbolize the profound and 
archaic fear of humankind of uncertainty. The principle of contingency that characterizes our daily lives leads us to make expiatory rites to secure our patrimony, genealogy and the connection with the Gods. Since all humans are equaled before the divinity, the conflict as a social indicator of inequality should disappear.

In sum, Dayan and Katz go on to question that "the notions of reinforcement and reproduction, obviously, are of great relevance for conceptualizing the effects of media events. While the most dramatic of our events deal with radical change, the theme of reinforcement of values and the sense of communitas permeate all of them. Indeed, most of the central events are salutes to the status quo, ligitimation of elites, and reiterations of the national well-being" (Dayan and Katz, 1994: 224). Once again, the mass media and electronic resources that characterize the late modernity are of paramount importance in the process of constructing a mediated event. Most likely, privileged groups which gained access to the material means of production in a Marxian sense exert considerable influence in the inception of a top-down ideological discourse. Nonetheless, this research is unable to represent the reality of Argentine bicentenary wherein there were precisely two upper politician sides which continued in their state of conflict even during this event.

\section{Methodological Discussion}

Founders of anthropology realized many years ago that there is a great dissociation between what people state and do. Because of many structural and cultural reasons, sometimes we are led to assume the beliefs and prejudices of others without explaining our behavior. For that reason, ethnography as a scientific method of research is of paramount importance to reveal the complex phenomenal world of interviewees. Truthfully, the literature in Event Management focuses on the application of open and close-end questionnaires and does not take into consideration the contributions of ethnography. Sometimes, ethnography is mistakenly identified with oral tape-recorded interviews. Nonetheless, some other alternative forms of research as participant observation are being misinterpreted. Ethnography, as something different from a methodology, refers to a strategy to enter in the field work where the researcher hears and views contexts in proximity with social actors. "Being there" is the primary criterion of distinction between ethnography and other methods. Since the bicentenary was a mega event very complex in its constitutions, we strongly believed the ethnography to be the best possible option to visualize how the social discourse works. In addition, by using diverse columns and articles published in Argentine newspapers, we reconstructed the discussion between Cristina Fernandez de Kirchner (President) and Mauricio Macri (Buenos Aires's Major).

\section{Chronicles of Argentine Bicentenary}

Ferdinand VII of Spain was imprisoned by Napoleon Bonaparte in 1801 and defeated United Kingdom in what specialists know as "Invasiones Inglesas" (English invasions), the atmosphere in the Viceroy ship Del Rio de la Plata was tense. A planned conference integrated by the most influential personage of Buenos Aires was held on $25^{\text {th }}$ May in 1810 to determine to whom the loyalty of this colony would be given, the King who was discredited by the imprisonment or Napoleon. Even though this event was not necessarily a sign of independence; this paved the way for the advent of local discontent, needs for autonomy and mistrust along with Spain, a situation that led to the final independence in 1819. This event was a turning point in Argentine history. From that day onwards, Argentines celebrated "the revolution of May" as one of most important patriotic dates.

In 1910 the failures and contributions of 80s generation were evident and more palpable. In such a context, Argentine Government of Jose Figueroa Alcorta opted to manage a special event to remind such a mythical event as the prerequisite for the advent of the independence. Basically, many celebrities and important European officials arrived in Buenos Aires for the celebration that took some days. As the epicenter of a wide range of festivals, Buenos Aires saw daunting parades, exhibitions, and other spectacles linked to encourage the idea enrooted in the "culture 
and civilization". The narrative of Centenary was aimed certainly to stress the benefits of European mass immigration to establish the scaffolding of family and the country's basis. Nevertheless, the situation in the region was not economically prosperous and some dissidents groups boasted for expanding their rights to more participatory democracy. As a result of this, in 1916, the 80 s generation set the pace for a new era free of voting frauds: ultimately, Hipolito Yrigoyen was elected president of Argentines and ruled up to 1922 when he was thrown out of the presidency by means of a coup.

Much more time has passed from that days but the spirit of centenary and May revolution have survived the test of time. On 25 May of 2010, President Cristina Fernandez de Kirchner had the opportunity to manage the bicentenary inviting many celebrities, artists and foreign officials. Unlike the first centenary where its primary discourse was certainly built around the European values, this event emphasized on values related to Human Rights (after the last bloody dictatorship 1976/1982), multiculturalism of diverse ethnicities, participatory civility and peace in the world.

\section{The Bicentenary today}

At a first glance, the bicentenary was celebrated during the series of memorials held $21,22,23,24$ and 25 May in 2010. To give this event a more emotional impact, the state planned to invite musicians, artists and players who freely staged a recital where more than 2 million attendants enjoyed. These celebrations were situated at 9 de Julio Avenue (which, no need to say, was closed to daily traffic). Important musicians were joined by Leon Gieco, Fito Paez, Gustavo Santaolalla, Lito Nebbia and Luis Alberto Spinetta as well as neighboring country presidents. The bicentennial parades congregated the presence of several artist groups which danced and passed exhibiting their national flags, customs and lore. The spirit of this event was reportedly enrooted into values as the interethnic tolerance, peace, human rights, and multi-culturalism. Since Argentine discourse is often coined in opposition to Anglo-world, neither the United States nor England was invited to this celebration. To some extent, this was intended to avoid a general whistling during the parade because of Malvinas/Falkland resentment. Let me remind readers that the US actively supported and coordinated the military action of United Kingdom in the above-mentioned episode.

What officials wanted to forge, for this event, was a wide-spread discourse of brotherhood with other Latin-American nations. Those countries, whose cultural legacy came from England, were not invited to this festival, with the exception of Scotland \& Ireland as ancient rivals to this colonial power. This means that the hostility of Argentines was not directed against Britishness, but Englanders only. The ego of Argentines, broken after Malvinas's war, was homologized to the ego of Englanders in Mexico 86s. As the previous argument given, in the streets many mythical canticles were certainly linked to "el que no salta es un ingles" (who does not jump is an Englishmen) and "volveremos a ser campeones como en el 86" (we will be champions again as Mexico 86) denoted a sentiment of chauvinism prior to the inauguration of the new World Cup in SouthAfrica 2010. There was a moment in the parade, when even the presenter echoed these canticles. Most certainly, the discourse of bicentenary was inextricably intertwined in the spirit of nationhood, the brotherhood between Latin American countries and a long-simmering rivalry with the Anglo-world.

However, the dichotomy was not resolved since Mauricio Macri, an Argentine businessman, the current major of Buenos Aires who is often linked to Argentines aristocracy, formulated a contrasting narrative of bicentenary based on civilization and highculture (in the inauguration of Colon's theatre). From his political debut in 2003, Macri discussed fiercely with Kirchner's couple (Nestor and Cristina) in "slippery" matters, such as the creation of metropolitan police, the union conflicts, and the various scandals which caused Macri to be investigated for spying opposition leaders illegally, including Macri's own party. As the previous background given, the bicentenary was far away of taming the conflicting interests and triggered a new scandal without precedents that darkened the celebrations. More or less, Macri as well as 
many liberals was identified to feel a profound admiration for the UK and the US.

\section{The Conflict in First Person}

Needless to say, an event of this caliber not only attracted more than two millions of attendants (tourists and local inhabitants) but also was broadcasted by the most important mass media and newspapers. Of course, following Dayan and Katz, the climate of bicentenary was characterized with harmony and social cohesion with one exception: the inauguration of Colon's Theatre, a significant ceremony organised by the Kirchner's staunch enemy, the Buenos Aires's Mayor Mauricio Macri. Against at odds, Cristina F. de Kirchner decided to not attend the performance of Colon generating a serious and deep seated debate between her supporters and detractors. Obviously, contrary to what literature points out, we were in the presence of how the social conflict was not only diminished but also potentiated a divergence between two bicentenaries (or at least two discourses). In parallel with this, Cristina F. Kirchner organised her own event in Buenos Aires; this means a mega-music festival wherein important players were invited. If the rivalry between Argentina and England would improve the social bondage as specialised studies indicate, the fact is that the bicentenary accelerated the conflicts in the core of Argentine government.

Newspapers and the media in general covered this troublesome episode under the lemma, historic festival beyond the political disputes, emphasising on the following values of ordinary citizens who congregated in the streets: a) patriotism, b) the lack of vandalism and conflict, $\mathrm{c}$ ) the role played by democracy in Argentina's history, d) the birthday motherland, e) the current state of development and prosperity in comparison with a hundred year ago. Strong emotions and pride worked as conduits for revitalising the "Argentineness" where the diplomatic disputes with UK for the Falkland / Mavinas and other discourses related to the conflicting relationship with US was plenty of opportunities. As the previous argument given, Mauricio Macri overtly stated that Fernandez de Kirchner took for the wrong turn at the time of deciding not to attend the
Colon's event. Anibal Fernandez, from the national government, replied that "The president was in her right to attend Colon when she wants" and, of course, this mediated discussion increased with the passing of hours. People in the streets thought that Mauricio Macri and Fernandez de Kirchner should leave behind their differences at least for one day, but the fact showed how a mega event whose anthropological goal is to strengthen the social liaison engendered the possibilities of facing two separated festivals, in other terms, two types of bicentenaries. Following this, while Colon's performance gave emphasis to high-culture, richness, sacrifice, work, Europeanness and conservatism, Kirchner's music festival inversely nourished a discourse based on multiculturalism, human rights, democracy, validating the achievement of her mandate.

Basically, Mauricio Macri accused CFK that her policies are demagogic, authoritarian, and populist while she replied with the state of injust liberalism left after 90s decade when Macri was a prosperous businessman. For CFK, M. Macri symbolises the complicity of certain sector of Argentine management that was in complicity with liberal policies that have driven the country to desperate levels of unemployment and a broader process of deindustrialisation. Similarly, the media overtly in enmity with Fernandez as Clarin, TN, La Nacion etc, stressed on the lack of liability not to attend Colon Theatre while El Argentino, 6/7/8 TV program and other pro Fernandez de Kirchner's media justified her decision because Macri represented the mind of an old anglophile aristocracy that accumulated not only riches, but also pushed the whole Argentine folk towards an state of pauperism and famine without precedents (first and foremost in complicity with former President Carlos Saul Menem who governed for two successive mandates from 1989 to 1999). Quite aside from this discussion, the polemic remained open and the scramble between Macri and CFK intensified with the time. In contrast with what Dayan and Katz said, mediated events (like this bicentenary) under conditions are temporarily unable to redeem the long simmering conflict and political disputes. Most likely, this did not happen 
during the burial of former president Nestor Kirchner (husband of Cristina) who died because of a sudden stroke. Especially for this event, supporters and dissidents suspended their discrepancies for a couple of days.

\section{Conclusion}

The bicentenary demonstrated how two politic beliefs that are mutually excluded coexisted in Argentina. One is constructed around the idea of civilisation, work, and europeanness while the other is aimed to re-discover the aboriginal roots, human rights and welfare distribution. The bicentenary as a mediated event found a much deeper division between Fernandez de Kirchner and Macri and the political conflicts in Argentina. The present paper was only an effort to describe how evolved the celebration in bicentenary was, as well as considering the possibility to revisit the Dayan and Katz's contributions along with the role played by social conflicts in the event management process. Basically, the following outcomes can be summarized in three relevant points:

a) The Bicentenary provoked long-simmering disputes between two contrasting discourses in politic fields. Distorted images of centenary from different aspects, give the preconditions for the advent of a stronger discourse that revitalise the heritage and helps citizenship understanding what being an Argentine means.

b) The binomial between development, which was associated to europeanness, and welfare, historically linked to distributions, was not only present but evident during bicentenary. This suggests that heritage, history, power and legitimacy are inextricably intertwined.

c) As a mediated event, the Bicentenary emphasised on the values based on nationhood and pride for national symbols in people. However, politicians seemed not to shorten their profound political disputes, contrasting exactly what specialised literature depicts.

Following Coser's (1961) contributions we might speculate that as a form of communication, conflict can take two different shapes: real and unreal. Whereas the former refers to the necessary instrumentality to achieve goals, this means for example the disputes seen during a conflict of concrete interests among two or more groups, the latter bespeaks of a much wider sociological issue enrooted in the needs to liberate anxieties by means of an scape goat. Following this explanation, fabricated conflicts are often aimed not only to create a discourse based on a tergiversated vision of history but also retrieve the past following personal or corporative interests. A dispute like this afore mentioned one, is very real because Kirchner and Macri represent contrasting values and interests but at some extent, both recurs to tergiversate the background of May revolution giving their own sense of what "being Argentine" means. As previous argument given, it is hypothesised that whilst unreal conflicts are not suspended during these types of events, real disputes are temporarily solved whenever a mediated event takes place. Sometimes, the indifference and lack of contact between groups or person helps reducing the existent hostility (Boulding, 1962). In foregoing, the social conflict as a mediator between groups is of paramount importance for practitioners, policy makers and planners of event management. Therefore, it is strongly needed to re-open a new channel of research along with the role played by disputes and social conflict in the event management. A more than interesting point of discussion that unfortunately, to the moment, studies linked to these types of issues do not focus on.

\section{References}

Agulla, J. C. (1986). Ideologías Políticas y Ciencias Sociales: La experiencia del Pensamiento Social Argentino (19551995). Buenos Aires: Editorial del Instituto de Derecho Público Ciencia Política y Sociología.

Allport, G. W. (1977). La Naturaleza del Prejuicio. Buenos Aires: Editorial Universitaria de Buenos Aires.

Anderton, C. (2009). Commercializing the Carnavalsque: the $\mathrm{V}$. and image/risk Management. Event Management, 12(1), 39-51.

Ashworth, G. J. (2008). Paradigms and Paradoxes in planning the past. In Smith, M. \& Onderwater, L. (eds.) Selling or Telling? Paradoxes in 
Tourism, Culture and Heritage. Arnhem: Atlas.

Baudrillard, J. (1997). For a Critique of the Political Economy of Sign. México: Siglo XXI.

Bauza, F. (1998). El Mito del Héroe: morfología y semántica de la figura heroica. Buenos Aires: Fondo de Cultura Económica.

Berlang-Adell, M. J. (2004). Turismo y Poder: las transformaciones de una fiesta popular en Marruecos. Pasos: Journal of Tourism and Cultural Heritage, 2(1), 25-45.

Binoy, T. A. (2011). Archeological And Heritage Tourism Interpretation: a study. South Asian Journal of Tourism and Heritage, 4(1), 100-105.

Boulding, K. (1962). Conflict and defense: a general theory. New York: Harper Torch- books.

Brewer, M. B. \& Campbell, D. (1976). Ethnocentrism and Intergroup Attitudes: East Africans Evidence. New York: Sage Publications.

Briones, C. (1998). La Alteridad del Cuarto Mundo: una reconstrucción antropológica de la diferencia. Buenos Aires, Ediciones del Sol.

Brown, R. (1998). Prejuicio, su Psicología Social. Madrid: Alianza Editorial.

Chew, M. (2009). Cultural sustainability and heritage tourism: problems in developing Bun Festival tourism in Hong Kong. Journal of Sustainable Development, 2(3), 34-42.

Cieslak, T. (2009). Match day security at Australian sport: a case of study of eight events. Event Management, 13(1), 43-52.

Coser, L. (1961). Functions of Social Conflicts. Buenos Aires: Fondo de Cultura Economica.

Crompton, J. \& Mckay, S. (1997). Motives of visitors attending festival events. Annals of Tourism Research, 24(2), 425-439.

Dayan, D. \& Katz, E. (1994). Media events. The live broadcasting of history. Cambridge, Harvard University Press.

Gelder, G. \& Robinson, P. (2009). A Critical comparative study of visitor motivations for attending music festivals: a case study of Glastenbury and $\mathrm{V}$ Festivals. Event Management, 13(3), 181-196.

Getz, D. (1991). Special Events. In Medlik, S. (ed.) Managing Tourism. Oxford: Butterworth-Heinemann, pp. 122-130.

Getz, D. \& Andersson, T. (2009). "Sustainable Festivals: on becoming an institution". Event Management, 12(1), 1-17.

Geertz, C. (2005). The Interpretation of Cultures. Barcelona: Editorial Gedisa.

Gonzalez-Reverté, F. \& Miralbell-Izard, O. (2009). Managing Music Festivals for Tourism perpuses in Catalonia (Spain), Tourism Review, 64(4), 53-65.

Graham, B., Ashworth, G. J. \& Tunbridge, J. E. (2000). A geography of heritage: power, culture and economy. London: Arnold Ed.

Guicci, G. (2007). La Vida Cultural del Automóvil: rutas de la modernidad cinética. Buenos Aires: Editora de la Universidad Nacional de Quilmes.

Hardin, R. (2003). Moralidad Institucional. In Goodin, E (ed.). Teoría del Diseño Institucional. Barcelona: Editorial Gedisa.

Hill, J. \& Varrasi, F. (1997). Creating Wembley: the construction of a national monument. The Sport Historian,17(2),28-43.

Hollingshead, K. (2009). 'Tourism State' cultural production: the re-making of Nova Scotia. Tourism Geographies, 11(4), 526-545.

Jonker, E., Saayman, M. \& De Klerk, S. (2009). The role and attributes of entrepreneurs at South Africa's largest arts festivals. Pasos: Journal of Tourism and Cultural Heritage, 7(3), 381-392.

Korstanje, M. (2008). El Ocio como mecanismo de Control Político: tras la búsqueda mítica del triunfo. Nómadas: revista crítica de Ciencias Sociales y Jurídicas. Universidad Complutense de Madrid. Junio-Diciembre.

Korstanje, M. (2009). Reconsidering the roots of event management: leisure in ancient Rome. Event Management, 13(3), 181-196.

Lorge, I. (1936). Prestige, suggestion, attitudes. Journal of Social Psychology, 8(2), 386-402. 
Maclver, R. M. \& Page, C. (1966). Sociology. Buenos Aires: Editorial Tecnos.

Mallen, C. \& Adams, J. (2008). Sport, recreation and tourism event management. London: Elsevier.

Mason, T. (1993). All the Winners and the Half Times. Sport in History, 13(1), 3-13.

McQuail, D. (1999). Introducción a la Teoría de la Comunicación de Masas. Madrid, Paidos.

Molloy, J. (2002). Regional Festivals: a look at community support, the isolation factor and funding sources. The Journal of Tourism Studies, 13(2), 2-15.

Noelle-Neumann, E. (1995). La Espiral del Silencio: opinión pública. Buenos Aires : Paidos.

Park, R. (1939). Race Relations and the Race Problem. Durham: Tristam Thompson.

Peterson, H. (1986). La Argentina y Los Estados Unidos: 1810-1914. Buenos Aires: Editorial Hyspamerica.

Pratto, F., Lemieux, A. F., Glasford, D. E. \& Henry, P. J. (2003). American and Lebanese college students' responses to the events of September 11, 2001, Psicología Política, 27(1), 13-35.

Prebensen, N. (2008). Investing in events: the case of a Sledge Dog race in Norway "The Finnmarksløpet". Event Management, 11(3), 99-108.

Prentice, R. \& Andersen, V. (2003). Festivals as a creative destination. Annals of Tourism Research, 30(1), 7-30.

Polley, M. (1998). The Diplomatic Background to the 1966 Football World Cup. Sport in History, 18(2), 1-18.

Ramshaw, G. (2011). The Construction of Sport Heritage Attractions. Journal of Tourism Consumption and Practice, 3(1), 1-25.

Ritchie, B. Sanders, D. \& Mules, T. (2007). Televised events: shaping destination image and perception of Capital cities from the Couch. International Journal of Event Management Research, 3(2), 12-23.
Robinson, P., Wale, D. \& Dickson, G. (2010). Event Management. Oxfordshire: CABI International.

Saayman, A. \& Saayman, M. (2006). Sociodemographic and visiting patterns of art festivals in South Africa. Event Management, 9(4), 211-222.

Seago, D. W. (1947). Stereotypes: Before Pearl Harbor and after. Journal of Psychology, 23, 55-63.

Sherif, M. \& Sherif, C. W. (1953). Groups in Harmony and Tension and Integration of Studies on Intergroup Relations. New York: Octagon.

Spivey, N. (2004). The Ancient Olympics: A history. Oxford University Press.

Stouffer, S. (1949). The American Soldier: Adjusting during Army Life. Princeton: Princeton University Press.

Tajfel, H. \& Turner, J. (1986). The social identity theory of intergroup behaviour, In Worchel, S. \& Austin, G. (eds.) Psychology of intergroup relations. Chicago: Nelson Hall, pp. 7-24.

Tassiopoulous, D. (2005). Event management: a professional and development Approach. Landsdowne: Juta Academics.

Urry, J. (2007). Introducción, Culturas Móviles. In Zusman, P., Lois, C. \& Castro, H. (eds.) Viajes y Geografías. Prometeo: Buenos Aires, pp. 17-31.

Uysal, M. \& Wicks, B. (1993). Festivals and events. Annals of Tourism Research, 20(4), 777-778.

Whitford, M. (2009). Oxaca's indigenous Gualegetza festival: not all that glisten is gold. Event Management, 12(3-4), 143-161.

Winter, M. F. \& Rins, C. (1996). La Argentina: una historia para pensar. Buenos Aires: Editorial Kapelusz.

Wright, A. S. (2010). Destination Ireland: an ancestral and emotional connection for American tourists. Journal of Tourism and Cultural Change, 7(1), 22-33. 